\title{
Efficient macrophage infection by phagocytosis of dying HIV-1 -infected CD4+T cells
}

\author{
Fedde Groot ${ }^{1 *}$, Rebecca A Russell ${ }^{1}$, Amy E Baxter ${ }^{1}$, Sonja Welsch², Christopher JA Duncan ${ }^{1}$, Christopher Willberg ${ }^{3}$, \\ Christina Ochsenbauer ${ }^{4}$, John C Kappes ${ }^{4}$, Michael Shaw ${ }^{1}$, Quentin J Sattentau ${ }^{1}$ \\ From Frontiers of Retrovirology 2011 \\ Amsterdam, The Netherlands. 3-5 October 2011
}

\section{Background}

Macrophages are scavengers of the innate immune system that eliminate dead and dying cells, and pathogens and pathogen-infected cells, but are also a major cellular reservoir for HIV-1 infection. HIV-1 is reported to infect macrophages by relatively inefficient processes of macropinocytic and endocytic uptake of cell-free virions. Earlier, we described directed cell-tocell spread via virological synapses between $\mathrm{T}$ cells and from macrophages to $T$ cells, a process of infection more efficient than cell-free uptake. However, the dominant mechanism by which HIV-1 spreads from its principal target, the $\mathrm{CD} 4+\mathrm{T}$ cell, to macrophages is unknown.

\section{Material and methods}

$\mathrm{T}$ cell lines and primary CD4+Tcells were infected with various HIV-1 strains, and were subsequently co-cultured with autologous (where applicable) monocytederived macrophages. Macrophage infection was qualitatively and quantitatively characterised using conventional and multispectral flow cytometry, confocal and electron microscopy, and detection of viral reverse transcription products by qPCR.

\section{Results}

Co-culture of HIV-1-infected T cells and macrophages rapidly led to detection of Gag and viral (v)DNA in macrophages, which peaked after 3 hours. Separation of macrophages and HIV-1-infected T cells by a viruspermeable membrane significantly decreased macrophage infection, demonstrating that cell-cell contact is essential for T cell-to-macrophage spread of HIV-1.

The Sir William Dunn School of Pathology, University of Oxford, OX1 3RE, UK

Full list of author information is available at the end of the article
Macrophage uptake of $\mathrm{T}$ cell-associated vDNA was not significantly reduced by blockers of viral Env-receptor interactions, viral fusion, or macropinocytosis. However, cytoskeletal paralysis and inhibition of dynaminactivity did significantly decrease HIV $-1+\mathrm{T}$ cell uptake. HIV-1 -infected CD4+ T cells with morphological and phenotypic features of apoptosis and necrosis were selectively phagocytosed by macrophages, resulting in gradual degradation of $\mathrm{T}$ cell-associated vDNA. However, productive HIV-1 infection of macrophages took place despite this, suggesting viral escape from degradation. Infectious molecular clones representing transmitted/ founder (T/F) HIV-1 have recently been derived, and were suggested to be non macrophage-tropic. However, although $\mathrm{T} / \mathrm{F}$ viruses demonstrated low macrophage infectivity in a cell-free form, phagocytosis of $\mathrm{T}$ cells infected with these viruses led to efficient macrophage infection.

\section{Conclusion}

We describe a novel mechanism of macrophage infection by macrophage recognition and clearance of dying HIV-1-infected CD4+T cells. Macrophage uptake of dying HIV-1-infected T cells is likely to take place at all times during the natural course of infection. However the highest impact will probably be during acute infection when transmitted virus infects a single, or a small number of permissive cells, forming an initial focus of infection. We predict that the massive apoptosis observed during the first weeks of acute HIV-1 infection in mucosal lymphoid tissue will lead to rapid recruitment of macrophages to engulf the dying cells, which thereby become infected forming a stable local virus reservoir. 


\section{Author details}

'The Sir William Dunn School of Pathology, University of Oxford, OX1 3RE, UK. ${ }^{2}$ Structural and Computational Biology, EMBL, D-69117 Heidelberg, Germany. ${ }^{3}$ The Weatherall Institute of Molecular Medicine, Nuffield Department of Medicine, University of Oxford, JR Hospital, OX3 9DU, UK. ${ }^{4}$ Department of Medicine, University of Alabama at Birmingham, Alabama, 35294, USA.

Published: 3 October 2011

doi:10.1186/1742-4690-8-S2-031

Cite this article as: Groot et al.: Efficient macrophage infection by phagocytosis of dying HIV-1 -infected CD4+T cells. Retrovirology 20118 (Suppl 2):O31.

Submit your next manuscript to BioMed Central and take full advantage of:

- Convenient online submission

- Thorough peer review

- No space constraints or color figure charges

- Immediate publication on acceptance

- Inclusion in PubMed, CAS, Scopus and Google Scholar

- Research which is freely available for redistribution

Submit your manuscript at www.biomedcentral.com/submit 